\title{
pragmatism and the unlearning of learnification
}

\author{
megan laverty 1 \\ columbia university, united states of america \\ maughn gregory ${ }^{2}$ \\ montclair state university, united states of america
}

\section{abstract}

Biesta thinks that teaching is imperiled by the contemporary emphasis on student learning and the constructivist epistemology behind it - a phenomenon he refers to as "learnification." For him, learning transforms the world into an object of understanding and adaption, positioning the self at its center. Biesta criticizes $\mathrm{P} 4 / \mathrm{wC}$ for falling in line with such learnification, for helping students to learn the critical thinking skills requisite to adapt themselves to global capitalism without critiquing it. Biesta uses pragmatism in general, and John Dewey's work on education in particular, to characterize and explain learnification, which makes his criticisms of $\mathrm{P} 4 / \mathrm{wC}$ all the more pointed, given the influence of Dewey on that movement. In this paper we challenge Biesta's use pragmatism as representative of learnification. We show that pragmatism offers important insights and practices that not only make learning richer than intelligent adaptation, but blurs the distinctions between adaptation and reconstruction, and between learning and ethical relationality. We argue that pragmatism neither devalues teaching nor restricts learning to the individual's mind. It promotes inquiry as a socially embedded, experimental, and indeterminate process of self/world reconstruction. We show connections between Biesta's Levinas-inspired focus on interruption, suspension, and sustenance, and the pragmatist emphasis on doubt, interest, and community of inquiry. For pragmatism, to learn is essentially to self-correct one's understanding, desire and/or behavior, but only as a result of being challenged and helped by others. Moreover, the experience of being changed by participation in a community is never merely hermeneutic or intellectual, but also always ethical, or even spiritual. We conclude, contrary to Biesta, that the pragmatism of Charles Peirce, Dewey, Richard Rorty, Matthew Lipman, Ann Margaret Sharp and Philip Cam conceives of constructivist education as a site for radical inter-subjective, inter-generational address and response, and for the radical questioning and subversion of personal, societal and cultural ways of life.

keywords: biesta; pragmatism; instrumentalism; teaching; philosophy for/with children.

\section{o pragmatismo e o desaprendimento da aprendização}

\section{resumo}

Biesta pensa que o ensino está em perigo pela ênfase contemporânea na aprendizagem dos alunos e a epistemologia construtivista por trás disso - um fenômeno que ele se refere como "aprendização". Para ele, aprender transforma o mundo em um objeto de compreensão e adaptação, posicionando o self no seu centro. Biesta critica P4/wC por se adaptar a essa aprendizagem, por ajudar os alunos a aprender as habilidades de pensamento crítico

\footnotetext{
${ }^{1}$ E-mail: laverty@tc.edu

2 E-mail: gregorym@mail.montclair.edu
} 
necessárias para se adaptarem ao capitalismo global sem criticá-lo. Ele usa o pragmatismo em geral, e o trabalho de John Dewey sobre a educação em particular, para caracterizar e explicar a teoria educacional construtivista, o que torna a sua crítica à Filosofia com e para Crianças mais afiada, dado a influência de Dewey naquele movimento. Neste artigo, desafiamos o pragmatismo de uso da Biesta como representante da aprendizagem. Mostramos que o pragmatismo oferece insights e práticas importantes que não só tornam a aprendizagem mais rica do que a adaptação inteligente, mas também desfigura as distinções entre adaptação e reconstrução e entre aprendizagem e relação ética. Argumentamos que o pragmatismo nem desvaloriza o ensino nem restringe o aprendizado à mente do indivíduo. Promove a investigação como um processo socialmente incorporado, experimental e indeterminado de auto-reconstrução do mundo. Mostramos conexões entre o foco de Biesta, inspirado por Levinas, na interrupção, suspensão e sustento, e a ênfase pragmática na dúvida, interesse e comunidade de investigação. Para o pragmatismo, aprender é essencialmente autocorrigir a compreensão, o desejo e / ou o comportamento de alguém, mas apenas como resultado de ser desafiado e ajudado por outros. Além disso, a experiência de ser alterada pela participação em uma comunidade nunca é meramente neural ou intelectual, mas também sempre ética, ou mesmo espiritual. Concluímos, contrariamente a Biesta, que o pragmatismo de Charles Pierce, Dewey, Matthew Lipman e Ann Margaret Sharp concebe a educação construtivista como um meio para um tratamento e resposta radicalmente intersubjetivas e inter-geracionais, e para o questionamento e subversão radicais dos modos de vida pessoal, social e cultural.

palavras-chave: biesta; pragmatismo; instrumentalismo; ensino; filosofia para e com crianças.

\section{el pragmatismo y el desaprendizaje de la aprendización}

resumen

Biesta piensa que la enseñanza está en peligro por el énfasis contemporáneo en el aprendizaje de los estudiantes y la epistemología constructivista detrás de él -un fenómeno al que se refiere como "aprendización". Para él, el aprendizaje transforma el mundo en un objeto de comprensión y adaptación, posicionando el yo en el centro. Biesta critica a P4/wC por estar en línea con tal aprendizaje, por ayudar a los estudiantes a aprender las habilidades de pensamiento crítico necesarias para adaptarse al capitalismo global sin criticarlo. Biesta utiliza el pragmatismo en general, y el trabajo de John Dewey sobre la educación en particular, para caracterizar y explicar la teoría educacional constructivista, lo que hace que sus críticas a $\mathrm{P} 4 / \mathrm{wC}$ sean aún más puntuales, dada la influencia de Dewey en ese movimiento. En este artículo desafiamos el uso de Biesta del pragmatismo como representante de la aprendización. Demostramos que el pragmatismo ofrece ideas y prácticas importantes que no sólo hacen que el aprendizaje sea más rico que la adaptación inteligente, sino que difumina las distinciones entre adaptación y reconstrucción, y entre el aprendizaje y la relacionalidad ética. Argumentamos que el pragmatismo ni devalúa la enseñanza ni restringe el aprendizaje a la mente del individuo. Promueve la investigación como un proceso social, inmerso, experimental e indeterminado de reconstrucción del yo / mundo. Mostramos conexiones entre el enfoque de Biesta inspirado en Levinas en la interrupción, suspensión y sustento, y el énfasis pragmático en la duda, el interés y la comunidad de investigación. Para el pragmatismo, aprender es esencialmente corregir la propia comprensión, deseo y/o 
comportamiento, pero sólo como resultado de ser desafiado y ayudado por otros. Además, la experiencia de ser cambiado por la participación en una comunidad nunca es meramente hermenéutica o intelectual, sino también ética, o incluso espiritual. Concluimos, al contrario de Biesta, que el pragmatismo de Charles Peirce, Dewey, Richard Rorty, Matthew Lipman, Ann Margaret Sharp y Philip Cam concibe la educación constructivista como un sitio para una dirección y respuesta intersubjetivas e intergeneracionales y para el cuestionamiento radical y subversivo de los modos de vida personal, social y cultural.

palabras clave: biesta; pragmatismo; instrumentalismo; enseñando; filosofía para/con niños. 
pragmatism and the unlearning of learnification

Mankind likes to think in terms of extreme opposites. It is given to formulating its beliefs in terms of Either-Ors, between which it recognizes no intermediate possibilities.

John Dewey

\section{biesta and the rediscovery of teaching}

In his keynote address to the 2017 meeting of the International Council for Philosophical Inquiry with Children (ICPIC) in Madrid, Spain (BIESTA, 2017b), Gert J.J. Biesta congratulated the Philosophy for/with Children (P4/wC) movement for having carved out a space for questioning in schools, before asking whether this is nearly enough. His encounters with $\mathrm{P} 4 / \mathrm{wC}$ in the classroom reveal an emphasis on argumentation informed by the Anglo-analytic tradition that does not engage students in speculative philosophizing or practical, non-discursive experimentation (BIESTA, 2017b). These precautionary remarks by Biesta echo earlier scholarship linking P4/wC with other philosophical traditions (DE LA GARZA 1990; MARTENS 1990; HARRICK 1993; KOHAN 1996; KIM 2004; MERÇON \& ARMSTRONG 2011), and calling for greater experiential engagement within $\mathrm{P} 4 / \mathrm{wC}$ (CEVALLOS, SIGURDARDOTTIR, 2000; GLASER, 2007; 2018; GREGORY, 2004). Biesta, however, is concerned that these tendencies or oversights are symptomatic of deeper problems, namely, instrumentalism - the reduction of $\mathrm{P} 4 / \mathrm{wC}$ to mere critical thinking - and mentalism - the tendency of $\mathrm{P} 4 / \mathrm{wC}$ practice to remain at the level of discursive thinking. Biesta is worried that our "philosophical work with children and young people ... does not really reach their heart or touch their soul" (BIESTA, 2017b, p. 418). Drawing on Emannual Levinas, he proposes that while P4/wC, focuses on the 'I' who raises questions, it overlooks the ' $\mathrm{I}$ ' who is in question (Biesta 2017b: 441).

To identify what is at stake in Biesta's challenge, we look to his recent scholarship that locates education and our coming to exist as subjects in encounters that "summon us to respond responsively and responsibly to otherness and 
difference in our own, unique ways" (2006, p. ix; see LAVERTY 2009). One of Biesta's most important ideas is that this summoning describes a kind of teaching or address that is imperiled by the contemporary emphasis on student learning and the constructivist epistemology behind it - a phenomenon he refers to as "learnification" (2006, 2010, 2017b). Learnification promotes a view of humanness as given by an ability to learn or to make sense. The problem, according to Biesta, is that sense making inevitably "puts the self at the centre and turns the world into an object for the self," and that to experience the self as the center of the world is to exist in an infantile or "egological" state (2017a, p. 31). He associates the freedom of signification (desire for understanding) with the freedom of choice (consumerism) and freedom of sovereignty (neo-liberalism) (BIESTA, 2017a), concluding that these kinds of freedom limit, rather than expand, humanity's existential possibilities. For Biesta, the existential and educational challenge is "to live in the world without occupying the center" (2017a: 8)

Biesta worries that $\mathrm{P} 4 / \mathrm{wC}$ falls in with the constructivist "logic of learning," thereby stultifying not only students' educational experience, but their very potential as human subjects. He uses pragmatism in general, and John Dewey's work on education in particular, to characterize and explain constructivist educational theory, which makes his critique of $\mathrm{P} 4 / \mathrm{wC}$ all the more pointed, given the influence of Dewey on that movement (see LIPMAN 2004; GREGORY; GRANGER 2012; LAVERTY 2016). The discipline of egotistical desire as an aim of education traces back to Socrates (see GARRISON, 1997), and Biesta is one among many educational philosophers and psychologists urging the renewal of this aim in our era of late capitalist neoliberalism. We understand neoliberalism to be an ideological commitment of the very privileged that defines, champions, and protects with violence the notion of freedom (liber) as the pursuit of unexamined desires in a freemarket economy, and which, as Biesta notes, "shift[s] responsibilities away from the collective towards individuals" (BIESTA, 2017b, p. 422). We share in Biesta's 
diagnosis that education has largely been co-opted to serve this ideology; that it largely prepares students to adapt themselves to the wealth-obsessed, violently unjust and ecologically doomed environment of late capitalism, and in fact largely disables them from being able to critique that environment (see GREGORY; LAVERTY 2009, 2010). However, we take issue with his use of pragmatism as representative of neoliberal education. We argue, on the contrary, that the pragmatism of Charles Peirce, Dewey, Richard Rorty, Matthew Lipman and Ann Margaret Sharp conceives of education as a site for radical inter-subjective, intergenerational address and response, and for the radical questioning and subversion of personal, societal and cultural ways of life (see LAVERTY, 2017).

\section{a pragmatist response}

Biesta seeks to provide "a robust and explicit account of the importance of teaching and the teacher" (BIESTA, 2017a, p. viii). Drawing on Levinas, he positions the teacher as Other who has the power to address the student as human subject and invite a non-egoistic response,

one that calls forth the subjectness of the student by interrupting its egocentrism, its being-with-itself and for-itself. This is not only a teaching that puts us very differently in the world .... We could even say that this teaching puts us in the world in the first place. It is (a) teaching that draws us out of ourselves, as it interrupts our ... desires, and in this sense, frees us from the ways in which we are bound to or even determined by our desires (BIESTA, 2016, p. 388).

Biesta argues that progressive education has devalued the teacher and teaching by representing him or her as a mere "fellow learner" in a classroom, in reaction against the perceived role of the teacher in traditional education as a source of authoritarian control (BIESTA, 2017a, p. 1). Yet, for Dewey, at least, the teacher was never merely learning along with the students (see GARRISON, 1997; GREENE, 1989; HANSEN 2001; JONAS, 2011). He famously chastised progressives for failing to recognize that children must be called to reconstruct themselves by their encounter with the teacher and the curriculum - which represent the accumulated and tested wisdom of the culture - and that, therefore, cultivation of children's intelligent activity 
requires "guidance given by the teacher" (1938/2008, p. 46). Teachers, through their mediation of cultural meaning and children's lived experience curate conditions "which give each present experience a worth-while meaning" (1938/2008, p. 30).

However, were Biesta to concede that progressive education calls for the intervention of the teacher, he would still criticize its view of "education as a learnercentered endeavor, where it is ultimately for learners to construct their own understandings and build their own skills, and where the main task of teachers is to provide arrangements in and through which such processes can happen" (BIESTA, 2016, p. 378). Biesta defines learning as meaning making - "interpretation and comprehension" - which is necessarily adaptive, in situating the student as an organism attempting to understand its environment well enough to adapt intelligently to it. He compares students under this view to robot vacuum cleaners that, "can learn or ... can adapt to their environment in an intelligent way ... by putting the machine in a different environment so that it needs to adapt to differing environing conditions.... While their learning remains a lifelong task-each new situation may pose new challenges and thus will require further (intelligent) adaptation-they may nonetheless become more skilled at adapting to new situations" (BIESTA, 2016, p. 378). Biesta sees learning as merely adaptive because it precludes the possibility of the student critiquing the environment to which it attempts to adapt itself, or questioning its desire to do so. For Biesta (2016, p. 387), "non-ego-logical" thinking must distinguish between the desired and the desirable, but "[t]he question that never arises ... is whether the environment to which the self is adapting and adjusting is good".

Significantly, Biesta levels this critique equally at individual and dialogical approaches to education (2016, p. 375). His comparison of students to robot vacuum cleaners is part of an ethical polemic, not a theory of mind; nevertheless, it assumes that there is a kind of learning that is essentially individualistic, that takes place or is constructed within an individual mind, rather than between or among language 
users. Pragmatist epistemology and learning theory eschews such a notion. For instance, Dewey (1916/2008; 1929/2008) mounted a critique of Plato's epistemology, which he characterized as a "spectator theory of knowledge," in which the mind can apprehend truth without a process of interpersonal justification or any other worldly transaction. Rorty echoed this critique of

Plato's metaphor of ascent to the indubitable ... to ... a kind of knowledge that was not discursive - a kind that did not rely on choice of a particular linguistic formulation. To reach truth that one cannot be argued out of is to escape from the linguistically expressible to the ineffable. (RORTY, 2016, p. 20-21).

Biesta's accusation that pragmatism promotes a kind of learning that occurs within individual minds ignores the history of pragmatist critique of Platonist epistemology on those very grounds.

Biesta's view of meaning-making as uncritical adaptation informs his warning that $\mathrm{P} 4 / \mathrm{wC}$ runs "the risk of instrumentalisation, that is, that philosophical work with children is understood as critical thinking, and that critical thinking is seen as nothing but a useful skill for navigating the uncertain world of ... global capitalism" (BIESTA, $2017 b$, p. 418). Biesta (2017b, p. 424) traces the roots of instrumentalist education to Dewey, but in fact, Dewey could not have countenanced such a view. Reconstruction was the leitmotif of Dewey's philosophy, educational and otherwise. He understood intelligence as the ability of organisms to sense what aspects of their interactions with the world are healthy, harmful, or potentially so, to make hypotheses for novel ways of thinking, feeling and acting intended to mitigate harms and induce growth, and to experiment until a better, if temporary, equilibrium is achieved. But reconstruction always involves changes both to the organism and to the environment. Dewey's seminal works on thinking - How We Think (1910) and Logic: The Theory of Inquiry $(1938 / 2008)$ - are important resources against the view of critical thinking as adaptation, because they describe inquiry as just this full-bodied, socially embedded, philosophically sensitive, experimental, and always indeterminate process of self/world reconstruction (LAVERTY, 2016). Dewey took from Peirce the idea that inquiry can only be prompted by a felt sense of doubt - a sense that something in 
one's current situation is unhealthy, vapid, or pointing toward potential growth. Dewey, in fact, saw philosophy as a range of existential doubts or challenges raised by various dimensions of most human beings' ordinary experience, including ethical, aesthetic, political, metaphysical and logical dimensions. On this view, the teacher's primary role is to prompt students to wake up to each of these dimensions of experience and to become sensitive to how the world, or one's corner of it, calls one to work on oneself and/or on the world, toward a particular kind of amelioration or growth (GREENE, 1978).

It was in this sense that Dewey called for education toward freedom of intelligence, which he defined as "freedom of observation and judgment exercised in behalf of purposes that are intrinsically worthwhile" (DEWEY, 1938/2008, p. 39). On this view, observation is more than simply seeing, hearing and touching; it involves discerning the meaning or value of what is observed. Freedom of intelligence is not aimed at adaptation to the given, but at the redirection of feeling and action because, as Dewey is keen to point out, our unexamined impulses and desires are not yet purposes. Dewey (1950/2008) discussed the desired/desirable distinction at length and stressed the importance of doubting one's desires. He called nonsensical "the notion that we are incapable of changing our desires and interests by means of learning what the consequences of acting upon them are, or, as it is sometimes put, of indulging them" (DEWEY, 1939, p. 218). In fact, what Biesta calls "interruption" of current habits of desire, is essentially what Pierce, Mead, and Dewey meant by "doubt". It was part of Dewey's critique of "child-centered" education that it ignored the role of the teacher to directly prompt such doubt.

But Dewey also argued that there is no blueprint for human nature or the beloved community that will tell us in advance of inquiry what is more and less desirable. Consequently, "[t]here is no a priori standard for determining the value of a proposed solution in concrete cases" (DEWEY, 1939, p. 232). That is why he championed democracy as a form of life in which we move out of ourselves to form 
associations, and our associations move out of themselves to form associations with other associations, every encounter being the occasion for new doubts to arise about what makes life more worth living. Biesta describes a subjectivity we are called into by being addressed in existential and ethical terms by other beings, especially teachers; but unless one believes in a supernatural ground for human nature, how is one to meaningfully adjudicate the divergent ethical claims made by others, including teachers, apart from pragmatic inquiry (see GREGORY, 2006)? As Rorty argued,

[t] here is ... no such thing as nondiscursive access to truth. The search for truth cannot be separated from the search for justification. There is no such thing as simply recognizing the truth when you see it - suddenly recollecting what you have always known, deep down inside. For we are not entitled to call our beliefs true unless we can give satisfactory reasons for them, satisfactory by the lights of those whom we accept as rational interlocutors (2016, p. 52).

The latter claim frankly admits that there is a certain insularity to communities of human inquiry in every time and place, but in the absence of an innate truthdetecting faculty there is simply no alternative for meaningful reconstruction of our beliefs, values and behaviors. This means that in order to interrupt the student's egological meaning making the teacher must enter into discourse with the student. And while the teacher may employ cultural resources to call students out of their egocentric perspectives, in discourse communities of radical equality students may also do this for each other, simply by confronting each other with their different experiences, beliefs, and values. The role of the teacher in such discourse communities is neither to encourage students' independent thought nor to guide them to predetermined conclusions, but to continually challenge the justifications they offer, to confront them with meaningful alternatives, to insist that they take seriously the divergent positions of others, and to hold them accountable for their choices. In Philosophy for Children it is expected that these teaching moves are soon learned by students in the community, so that this indispensable role of the teacher is increasingly "distributed" among the entire community. In any case, once challenged, 
each student must then decide what to believe, value or do, and has no other means of doing so than by participating in this very kind of discursive and experimental inquiry. It is for this reason that Rorty concluded that

[i]ntellectual and moral progress is not a matter of getting closer to an antecedent goal but of surpassing the past.... What we call 'increased knowledge' should not be thought of as increased access to the Real but as increased ability ... to take part in social practices that make possible richer and fuller human lives. (RORTY, 2016, p. 5).

Biesta asserts that the task of education is to "arous[e] the desire in another human being for wanting to exist in and with the world in a grown-up way, that is as subject" (BIESTA, 2017a, p. 7). But this task is not all that different from Dewey's concluding remark in Democracy and Education, that "[i]nterest in learning from all the contacts of life is the essential moral interest" (DEWEY, 1916/2008, p. 370; See HANSEN, 2006, pp. 165-187). Dewey deliberately does not locate the essential moral interest in simply "learning from all the contacts of life" or in "adapting oneself to all the contacts in life" because interest for him is a desire for the most cherishable kinds of experience that certain ways of life make possible (JONAS, 2011). Thus, P4/wC understood through the lens of pragmatism contains within itself possibilities for speculative philosophizing and practical experimentation. But then this makes Biesta's critique of certain versions of $\mathrm{P} 4 / \mathrm{wC}$ as wholly verbal and intellectual exactly right, as others in the movement have pointed out (CEVALLOS; SIGURDARDOTTIR, 2000; GLASER, 2007; 2018; GREGORY, 2004). Following Dewey, those of us involved in philosophical work with children must honor philosophy as a site not only for problem-posing of a radical kind, but for experimenting with possible solutions that may very well call for the reconstruction of the self, the school, the home, and the larger society. ${ }^{3}$ Sharp (2009), for instance, called for Philosophy for/with Children to become radicalized in this way, in her writing on the child as critic.

\footnotetext{
${ }^{3}$ Compare Rorty's assertion that "experience is our only teacher when it comes to deciding which new proposals to dismiss as fancy and which to praise as imaginative. If we can cease to feel the urge ... to rise above the ambiguous lessons of accumulated experience and to find ahistorical criteria by which to justify our decisions, we can combine Shelly's ebullient praise of the imagination with Dewey's
} 
Another danger of learning as meaning making, for Biesta, is that it objectifies the student because it is wholly self-generated, in that, "acts of interpretation and comprehension have an egological structure that emanates from the self and returns to the self, even if this occurs 'via' the world (BIESTA, 2016, p. 376). Biesta's term "egological" signifies that the meaning-making self is trapped within its selfinterested understandings and desires and encounters the world only as means and obstacles to its ends. It is in this way that the learnification of contemporary education robs students of their human subjectivity. "[T]he very 'thing' that cannot happen," for students as self-constructed learners, "the very 'thing' that can never 'arrive' in their universe, is the event of being addressed, that is, the event of being taught (BIESTA, 2016, p. 388). This concern is echoed in Biesta's distinction between schools as "places for learning" and "places of encounter, where people come together" (BIESTA, 2017b, p. 419). Yet, the two sides of that distinction essentially comprise the two terms in the pragmatist notion of the "community of inquiry," which is the basis of the Lipman/Sharp approach to $\mathrm{P} 4 / \mathrm{wC}$. The notion originated with Peirce, who understood that the limitations and errors in one's own observations, thinking and judgment require one to participate in a community of peers who may correct one another's errors and extend one another's ideas. Peirce's notion of "self-correction" (now central to constructivism) was part of this broader notion of a collaborative community. To learn is essentially to self-correct one's understanding, desire and/or behavior, but only as a result of being challenged and helped by others; and communities as well as individuals are in continual need to self-correct. Moreover, for Peirce, the experience of being changed by participation in a community was never merely hermeneutic or intellectual, but also always ethical, even spiritual: part of the cosmic movement toward agape that he referred to as "evolutionary love" (PEIRCE,

sober insistence that moral and political progress will always require willingness to make dangerous experiments... If we could test for an idea's utility in advance of trying it out in practice, there would be no need for risky experiments. But a world in which that risk is absent would be one in which we were not the finite, time-bound creatures that we are.... [P]ragmatism is a philosophy of finitude" (2016, p. 36-7). 
1893; see SHARP, 1993). Rorty offered a more modest but equally moral view of inquiry when he wrote that,

[a]nother meaning for 'rational' is ... something like 'sane' or 'reasonable' rather than 'methodical.' It names a set of moral virtues: tolerance, respect for the opinions of those around one, willingness to listen, reliance on persuasion rather than force.... On this construction, to be rational is simply to discuss any topic - religious, literary, or scientific - in a way which eschews dogmatism, defensiveness, and righteous indignation. (RORTY, 1991, p. 38).

Again, to model and invite students into this ethically demanding and epistemologically risky kind of discourse is the role of the teacher of the community of philosophical inquiry.

Similarly, for Sharp (1995), the community of inquiry is always an ethical practice. Biesta notes that "philosophical work with children is particularly strong in helping children and young people to ask questions," but argues that "[t]he subject position that is made available in this way, is that of the I who asks questions, who makes sense, who seeks to understand" (BIESTA, 2017b, p. 434). However, participants in the community of inquiry are compelled to recognize that this kind of personal sense-making can only happen in a space of mutual vulnerability. Sharp and Laverty (2018), in fact, draw on Levinas to argue that "caring thinking" in the community of inquiry has ontological meaning beyond its epistemological utility.

\section{conclusion: beyond oppositional thinking}

To draw upon Biesta's language, $\mathrm{P} 4 / \mathrm{wC} \mathrm{creates}$ a communicative space of interruption, suspension and sustenance, intended to support students "with staying in the middle way" (BIESTA, 2017a, p. 19). The community of philosophical inquiry is "a process through which our desires receive a reality check" (BIESTA, 2017a, p. 16) including even our desire for understanding, which is of such concern to Biesta. The pragmatist recommendation not to think of this as a capital-R Reality check does not mean the check is any less severe. Students in $\mathrm{P} 4 / \mathrm{wC}$ encounter resistance insofar as they find themselves in a circle with a teacher and fellow students who put each other into question at the same time that they each have something to say and a first-person 
point of view. In fact, Biesta effectively describes the community of philosophical inquiry when he writes (of the middle way) that it is "not a place of pure selfexpression, but rather a place where our self-expression encounters limits, interruptions, responses" (BIESTA, 2017a, p. 10). The community of philosophical inquiry is a worldly experience because it prohibits students from either destroying or retreating from the world; it is "the place where a grown-up way of being with what and who is other might be achieved" (BIESTA, 2017a, p. 10). It cultivates subjectness by fostering the attention and commitment needed for sustained self-, other- and world-questioning and dialogue (BIESTA, 2017a, p. 15). It creates "time, space and forms so that students can encounter their desires, examine their desires, select and transform them" (BIESTA, 2017a, p. 20).

Biesta concedes "that learning can be a richer concept than what is captured in the idea of intelligent adaptation," though at the same time he stresses "that to the extent to which our understanding of learning relies on the 'paradigm' of intelligent adaptation, it is significantly lacking, both humanely and educationally" (BIESTA, $2017 b$, p. 426-7). While we strongly agree with the latter, we argue that pragmatism offers important insights and practices that not only make learning richer than intelligent adaptation, but blurs the distinctions between adaptation and reconstruction, between self-correction and communal inquiry, and between learning and being in ethical relationship with others. $\mathrm{P} 4 / \mathrm{wC}$ invites teachers and students to speak to one another as it introduces them to a curriculum that models young people questioning and talking together about which desires qualify as desirable. As students become subjects of their desires, rather than subjected to them, are they learning or receiving a teaching? We are inclined to say that they are doing both.

\section{references}

BIESTA, Gert J.J. (2006). Beyond Learning: Democratic Education for a Human Future. Boulder CO: Paradigm Publishers.

BIESTA, G.J.J. (2010). Good Education in an Age of Measurement: Ethics, Politics, Democracy. London: Paradigm Publishers. 
BIESTA, Gert J.J. (2016). The Rediscovery of Teaching: On robot vacuum cleaners, non-egological education and the limits of the hermeneutical world view. Educational Philosophy and Theory 48(4): 374-92.

BIESTA, Gert J.J. (2017a). The Rediscovery of Teaching. London and New York; Routledge.

BIESTA, Gert J.J. (2017b). Touching the soul? Exploring an alternative outlook for philosophical work with children and young people. Childhood E Philosophy 13(28): 415-452.

CEVALLOS, Pablo and SIGURDARDOTTIR, Brynhilder (2000). The Community of Inquiry as Means for Cultivating Democracy. Inquiry: Critical Thinking Across the Disciplines 19(2): 45-57. DE LA GARZA, Tere (1990). Jose Ortega y Gasset and Eduardo Nicol: Alternatives for Philosophical Foundation of Philosophy for Children in Latin America. Analytic Teaching 10(2): 2226.

DEWEY, John (1916/2008). John Dewey: The Middle Works 1899-1924, Volume 9: 1916, Democracy and Education. Jo Ann Boydston, Ed. Carbondale: Southern Illinois University Press.

DEWEY, John (1929/2008). John Dewey: The Later Works 1925 - 1953, Volume 4: 1929, The Quest for Certainty. Jo Ann Boydston, Ed. Carbondale: Southern Illinois University Press.

DEWEY, John (1933/2008). How We Think. In Jo Ann Boydston (Ed.) John Dewey: The Later Works 1925-1953, Volume 8: 1933, pp.105-352. Carbondale: Southern Illinois University Press.

DEWEY, John (1938/2008). Experience and Education. In Jo Ann Boydston (Ed.) The Later Works of John Dewey, Volume 13, 1925 - 1953: 1938-1939, Experience and Education, Freedom and Culture, Theory of Valuation, and Essays, pp. 1-6. Carbondale, IL: Southern Illinois University Press.

DEWEY, John (1938/2008). The Later Works of John Dewey, Volume 12, 1925 - 1953: 1938, Logic: The Theory of Inquiry. Jo Ann Boydston, Ed. Carbondale, IL: Southern Illinois University Press. DEWEY, John (1939). Theory of Valuation. In Jo Ann Boydston (Ed.) John Dewey: The Later Works 1925-1953, Volume13: 1938 - 1939, pp. 189-252. Carbondale: Southern Illinois University Press. DEWEY, John (1950/2008). Comment on Recent Criticisms of Some Points in Moral and Logical Theory. In: BOYDSTON, Jo Ann (Ed.) John Dewey: The Later Works 1925-1953, Volume17: 1885 1953, pp.480-4. Carbondale: Southern Illinois University Press.

GARRISON, Jim (1997). Dewey and Eros: Wisdom and Desire in the Art of Teaching. New York, Teachers College Press.

GLASER, Jennifer (2007). Educating for Citizenship and Social Justice. In: CAMHY, D.

(Ed.) Philosophical Foundations of Innovative Learning, pp.16-25. Germany: Academia Verlag. GLASER, Jennifer (2018). Social and Political Dimensions of the Community of Philosophical Inquiry in an Age of Globalization. In M.R. Gregory and M.J. Laverty (Eds). In Community of Inquiry with Ann Margaret Sharp: Philosophy, Childhood and Education, pp. 217-29. London and New York: Routledge.

GREENE, Maxine (1978). Landscapes of Learning. New York: Teachers College Press.

GREENE, Maxine (1989). The Teacher in John Dewey's Works. Teachers College Record 90(5): 24-35.

GREGORY, Maughn (2004). Practicing Democracy: Social Intelligence and Philosophical

Practice. International Journal of Applied Philosophy 18(2): 161-174.

GREGORY, Maughn (2006). Pragmatist Value Inquiry. Contemporary Pragmatism 3(1): 107-128. GREGORY, Maughn; GRANGER, David (Eds.) (2012). John Dewey and the child as philosopher [Special issue]. Education and Culture: The Journal of the John Dewey Society, 28(2). ("John Dewey on Philosophy and Childhood," introductory essay, pp. 1-25.)

GREGORY, Maughn; LAVERTY, Megan Jane (Eds.) (2010). Philosophy, Education and the Care of the Self [Special issue]. Thinking: The Journal of Philosophy for Children, 19(4). ("Philosophy, education and the care of the self," introductory essay, pp. 3-9.)

GREGORY, Maughn; Laverty, Megan Jane (2009). Philosophy and Education for Wisdom. In KENKMANN, A. (Ed.), Teaching Philosophy (pp. 155-173). London, UK: Continuum International. 
pragmatism and the unlearning of learnification

HANSEN, David T. (2001). Exploring the Moral Heart of Teaching: Toward a Teacher's Creed. New York: Teachers College Press.

HANSEN, David T. (2006). Dewey's Book of the Moral Self. In David T. Hansen (ed.), John Dewey and our Educational Prospect: A Critical Engagement with Dewey's "Democracy and Education", pp. 165-187. Albany: State University of New York.

HARRICK, William (1993). Phenomenology and the Philosophy for Children Program. In LIPMAN, Matthew (Ed.) Thinking Children and Education, pp. 410-415. Iowa: Kendall/Hunt Publishing Co.

JONAS, Mark (2011). Dewey's Conception of Interest and its Significance for Teacher Education. Educational Philosophy and Theory 43(2): 112-129.

JUUSO, Hannu (2002). P4C in the Light of Hegel's Thought. Critical and Creative Thinking: The Australasian Journal of Philosophy in Education 10(2): 20-35.

KIM, Jung Yeup (2004). The Dao of Philosophy for Children. Thinking: The Journal of Philosophy for Children 17(1-2): 69-72.

KOHAN, Walter O. (1996). Heraclitus and the Community of Inquiry. Analytic Teaching 17(1): 3443.

LAVERTY, Megan Jane (2009). Review of Beyond Learning: Democratic Education for a Human Future by Gert J.J. Biesta. Studies in Philosophy and Education 28(6): 569-576.

LAVERTY, Megan Jane (2016). Thinking My Way Back to You: John Dewey on the Communication and Formation of Concepts. In Andrea English \& Mordechai Gordon (eds.) "Dewey's Democracy and Education in an Era of Globalization," [special issue] Educational Philosophy and Theory 48(10): 1029-1045.

LAVERTY, Megan Jane (2017). Communication as Translation: Reading Dewey after Cavell. In Standish, Paul; SAITO, Naoko (eds.) Stanley Cavell and Philosophy as Translation, pp. 121-40 London: Rowan \& Littlefield.

LIPMAN, Matthew (2004). Philosophy for Children's Debt to Dewey. Critical \& Creative Thinking: The Australasian Journal of Philosophy in Education. 12(1): 1-8.

MARTENS, Ekkehard (1990). Philosophy for Children and Continental Philosophy. Thinking: The Journal of Philosophy for Children 9(1): 2-7.

MERÇON, Juliana; ARMSTRONG, Aurelia (2011). Transindividuality and Philosophical Enquiry in Schools: A Spinozist Perspective. Journal of Philosophy of Education 45(2): 251-64.

PEIRCE, Charles S. Evolutionary Love. The Monist 3: 176-200, 1893.

RORTY, Richard. Objectivity, Relativism and Truth. New York: Cambridge University Press, 1991. RORTY, Richard. Philosophy as Poetry (Charlotesville: University of Virginia Press), 2016.

SHARP, Ann Margaret. The Child as Critic. In E. Marsal, T. Dobashi and B. Weber (Eds.) Children Philosophize Worldwide, pp. 201-208. New York: Peter Lang, 2009.

SHARP, Ann Margaret; LAVERTY, Megan Jane (2018). Looking at Others' Faces. In: GREGORY, M.R.; LAVERTY, M.J. (Eds.) In Community of Inquiry with Ann Margaret Sharp: Philosophy, Childhood and Education, pp. 120-30. London: Routledge.

SHARP, Ann Margaret. Philosophy for Children and Development of Ethical Values. Early Childhood and Care 107: 45-55, 1995.

SHARP, Ann Margaret. Peirce, Feminism and Philosophy for Children. Analytic Teaching 14(1): 5162, 1993.

received in: 14.08 .2017

accepted in: 11.09.2017 